\title{
CD36 Negative
}

National Cancer Institute

\section{Source}

National Cancer Institute. CD36 Negative. NCI Thesaurus. Code C162067.

An indication that CD36 expression has not been detected in a sample. 